\title{
O DRAMA DA EDUCAÇÃO EM PORTUGAL
}

Fernando Cortes Leal

Professor especializado em Alta Direcção para a Administração Pública, Portugal

O miserabilismo que enforma o estado geral da educação em Portugal é suficientemente esclarecedor para que a sua dramática realidade e as suas quase irreparáveis consequências sociais possam continuar a ser levianamente subestimadas pelos sucessivos governos da nação. Importa, por isso, clarificar e consensualmente assumir, sem reservas morais e sem desnecessários pruridos ideológicos, que o actual desempenho nacional em matéria educativa é excessiva, absurda e inexplicavelmente mau (!).

De há muito que repetidamente se indaga o "porquê?" dos nossos acumulados défices educativos, sem que, com tal obsessão diagnóstica, se tenha feito algo mais que não seja prolongar e arrastar até aos dias de hoje essa inconsequente "idade dos porquês".

Apesar de o Estado providencial se fragilizar a cada dia que passa, devido, sobretudo, à comprovada insustentabilidade económica e financeira necessária à provisão das suas tradicionais políticas públicas proteccionistas, em matéria educativa não apenas se insiste em desprezar a dimensão orçamental e o consequente impacto político e social dos insuportáveis custos com ela dispendidos, como, pior ainda, teima-se em sonegar os sofríveis resultados por ela obtidos.

A verdade, porém, é que a educação nacional configura-se cada vez mais como um colossal mas estéril monstro politicamente desgovernado, administrativamente incontrolável e financeiramente insaciável.

A imensidão de debilidades acumuladas pelo sistema educativo português desenha um estado de desgraça que começa no arcaico e amador modelo de gestão das escolas, passeia-se na ineficiência dos redundantes e labirínticos níveis hierárquicos dos serviços centrais e regionais do Ministério da Educação, continua no generalizado subaproveitamento dos recursos humanos e no gigantesco desperdício de recursos financeiros, para, entre outras perversidades mais, se apresentar como inveterado militante da manutenção das rotinas e por isso cronicamente avesso à mudança, à inovação e à satisfação das reais e prioritárias necessidades de desenvolvimento social e económico do país.

O mais espantoso de tudo isto é não só a indiferença política com que é vista a deterioração da educação pública em Portugal, mas também, e particularmente, a inexplicável primazia que na concepção ideológica das políticas educativas continua a ser concedida aos arautos do "laisser faire, laisser passer", os quais impunemente insistem em transformar as escolas e as práticas de ensino e de aprendizagem numa espécie de "brincolândia nacional".

Com efeito, as teorias pedagógicas facilitistas que ainda povoam a cultura e o imaginário escolar, e que se fazem corresponder a uma visão romântica de sociedade que a falência do Estado providência provou ser perversa para o desenvolvimento pessoal e social dos nossos alunos, transmitem a ideia errada de que a vida fora da escola é tão fácil quanto o é no interior dos seus portões, onde graça a ausência de disciplina, rigor e responsabilidade. 
A realidade nua e crua dos factos diz-nos que a rentabilidade do sistema educativo português e o seu grau de eficiência oscilam entre metade e dois terços dos níveis de proficiência obtidos pelos sistemas educativos de outros países europeus de dimensão comparável. Demonstram-no os relatórios da OCDE ("Education at a Glance" e o estudo PISA, ambos de 2003), os quais, cruzados entre si, permitem verificar que o problema da educação nacional se coloca ao nível da qualidade do investimento em educação e não tanto no da sua quantidade. Isto é, ao tomar em conta os indicadores de desempenho do nosso sistema educativo, constata-se que este é absurdamente ineficiente e irracionalmente dispendioso.

Gastamos com a educação mais do que a média dos países da OCDE e mais do que a União Europeia(!). Dito de outro modo, não é por falta de investimento que, numa primeira análise, se explicam os baixos níveis de desempenho obtidos por Portugal no ranking internacional. Pelo contrário, se com este nível de despesa com a educação (cerca de $6 \%$ do PIB nacional), tivéssemos o mesmo índice de produtividade que o país melhor classificado dos 20 comparados no citado estudo "Education at a Glance", teríamos, em termos de eficácia comparada do sistema, um resultado cerca de $50 \%$ superior àquele que efectivamente detemos.

Apesar de gastarmos mais em educação do que a maioria dos nossos parceiros europeus, somos, ainda assim, tristes recordistas nas taxas de iliteracia e nas taxas de abandono e de insucesso escolares. Um rápido e sumário relance pelos dados estatísticos disponíveis, permite-nos traçar os contornos do quadro negro em que se encontra a educação em Portugal:

- Mais de 2,5 milhões de portugueses não possuem a escolaridade mínima obrigatória;

- Apenas $20 \%$ da nossa população possui o $12^{\circ}$ ano, quando a média da OCDE é de $65 \%$;

- $67 \%$ dos cidadãos nacionais não tem mais de seis anos de escolaridade e somente $9 \%$ possui educação de nível superior contra a média de $24 \%$ verificada na OCDE;

- Perdemos, por abandono escolar, cerca de $45 \%$ dos alunos até ao $12^{\circ}$ ano, incomparavelmente o número mais elevado de toda a Europa;

- Apesar de enganadoramente possuirmos na actualidade taxas de escolarização próximas das da União Europeia, não podemos escamotear que tal facto decorre sobretudo do excessivo peso do número de alunos repetentes que se encontram no sistema;

- Detemos, em plena sociedade do conhecimento, uma vergonhosa percentagem de adultos no activo que não tem acesso à formação profissional (só 3\% da população activa frequenta acções de formação contínua com uma duração de pelo menos 6 horas mensais).

Face ao confrangedor panorama aqui lacunarmente retratado, importará desmistificar as causas que alegadamente se dizem estar na sua origem. De entre os argumentos mais invocados para supostamente justificar o défice educativo nacional, avultam o do alegado número excessivo de alunos por turma e o da desmotivação profissional dos docentes devido a um hipotético baixo nível de compensações remuneratórias. Os factos, contudo, provam a falsidade de ambos os argumentos:

- Relativamente ao número de alunos por turma nas escolas portuguesas, verifica-se que, em termos comparativos, detemos o ratio alunos/professor mais baixo da União Europeia, 
ocupando, relativamente à OCDE, o $5^{\circ}$ lugar na relação professor/aluno no ensino básico (1 professor para 12 alunos) e o 15임 lugar no ensino secundário;

- No que se refere ao nível de remunerações auferido pelos docentes, verificamos que os professores do ensino básico português são dos mais bem pagos de toda a União Europeia, e que a generalidade dos docentes dos diferentes níveis e graus de ensino situa-se no patamar médio alto das retribuições salariais praticadas na Europa. Acresce, ainda neste capítulo, que ao contrário dos nossos parceiros europeus, a progressão na carreira remuneratória por parte dos docentes portugueses não se encontra vinculada a qualquer cláusula de produtividade, nem existe no panorama nacional mecanismos de discriminação positiva diferenciadores do bom e do mau desempenho docente, o que, como é sabido, faz com que as más práticas tendam a massificar-se contagiosamente, conduzindo à anemia dos processos de organização do ensino e da aprendizagem e à diminuição global dos índices de produtividade profissional e organizacional.

O genérico cenário da educação portuguesa aqui traçado, enfatiza com acentuada acuidade a exigência de racionalidade no gasto público com a educação. Aos políticos incumbe, com carácter de urgência, perceber que se ao volume da despesa pública realizado em Portugal com a educação não se fazem obter e corresponder os resultados proporcionais que seriam razoavelmente de esperar, torna-se então necessário que com igual ou até com menor volume de investimento se reequacionem prioridades educativas e se refaçam os modelos sistémicos de organização e de administração educacional, a começar, ao nível local, pela necessária profissionalização da gestão das escolas.

A profissionalização da gestão escolar, impõe-se como condição basilar de eficácia mínima garantida não apenas para promover a requalificação organizacional das escolas, mas sobretudo para assegurar o êxito e a sustentabilidade da necessária descentralização administrativa, pedagógica e financeira e da consequente responsável assunção da sua autonomia institucional.

A reforma educativa que se impõe incide não apenas na profunda e absolutamente necessária revisão dos currículos da educação básica e do ensino secundário, mas também no de toda a organização e gestão do sistema. Reforma não somente no seu modo de organização administrativa e pedagógica, mas também nos seus modelos de provisão social, os quais se deverão flexibilizar no sentido de promover a livre emergência da oferta educativa por outros sectores da sociedade (particularmente pelo privado) que possam não somente aliviar o Estado na sua cada vez mais insustentável condição de provedor único, mas também de, através dessa via, por uma lado dilatar a liberdade de escolha dos cidadãos e, por outro, de elevar competitivamente o nível geral da qualidade da educação em Portugal. 


\title{
Contactar
}

Revista lberoamericana de Educación

\author{
Principal OEI
}

